\title{
PENGARUH PENDEKATAN PROJECT BASED LEARNING TERHADAP KEMAMPUAN KOMUNIKASI MATEMATIS DAN DISPOSISI MATEMATIS SISWA SMA NEGERI 1 NGABANG
}

\author{
Bernadeta Ritawati \\ Pendidikan Matematika STKIP PAMANE TALINO \\ b.ritawati@stkippamanetalino.ac.id
}

\begin{abstract}
Abstrak
Tujuan penelitian ini adalah: (1) mengkaji kemampuan disposisi matematis dalam materi bangun ruang sesudah diberikan pembelajaran menggunakan pendekatan Project Based Learning; (2) mengkaji kemampuan komunikasi matematis dalam materi bangun ruang sesudah diberikan pembelajaran menggunakan pendekatan Project Based Learning; dan (3) mengetahui besar kontribusi pendekatan Project Based Learning terhadap kemampuan komunikasi matematis dalam materi bangun ruang. Bentuk penelitian ini adalah kuantitatif. Sedangkan pendekatan yang digunakan dalam penelitian ini adalah One Group Pretest Posstest Study. Subjek populasi penelitian ini adalah seluruh siswa kelas XII SMA Negeri 1 Kabupaten Landak, dengan sampel siswa kelas XII. Hasil yang diperoleh adalah: (1) kemampuan disposisi matematis dan komunikasi matematis dalam materi bangun ruang sesudah pembelajaran menggunakan pendekatan Project Based Learning tergolong tinggi; (2) pendekatan Project Based Learning sangat mempengaruhi kemampuan komunikasi dan disposisi matematis siswa dalam materi bangun ruang.

Kata Kunci: Project Based Learning, Komunikasi Matematis, Disposisi Matematis, Geometri.
\end{abstract}

\begin{abstract}
The purposes of this study are: (1) to assess the of a mathematical disposition in a given three domensional shapes after learning use of Project Based Learning approach; (2) to assess the of mathematical communication in a given three domensional shapes after learning use of Project Based Learning approach; and (3) know the contribution of Project Based Learning approach to mathematical communication in three domensional shapes. The population of this study is all twelve grade students of SMA Negeri Kabupaten Landak class XII. The selected samples are class XII students. The results are: (1) the of mathematical disposition and mathematical communication in three domensional shapes after a given learning use Project Based Learning approach is relatively high; (2) Project Based Learning approach greatly affect of students mathematical communication and disposition of in three domensional shapes.
\end{abstract}

Keywords: Project Based Learning, Mathematics Communication, Mathematics Disposition, Geometry

\section{PENDAHULUAN}

Pendidikan di Indonesia menurut Departemen Pendidikan dan Kebudayaan (Depdikbud) bertujuan untuk mengembangkan potensi siswa agar memiliki kecerdasan, berakhlak mulia serta memiliki keterampilan yang diperlukan sebagai anggota masyarakat dan warga Negara (Depdikbud, 2013). Satu di antara mata pelajaran yang diamanahkan untuk mengembangkan potensi siswa adalah matematika.

Tujuan diberikannya matematika di sekolah antara lain siswa dapat: (1) mengkomunikasikan gagasan dengan simbol, tabel, diagram, atau media lain untuk memperjelas keadaan atau masalah; (2) memiliki sikap menghargai kegunaan matematika dalam kehidupan, yaitu memiliki rasa ingin tahu, perhatian dan minat dalam mempelajari matematika, serta sikap ulet dan percaya diri dalam pemecahan masalah. (BSNP, 2006: 140).

Kedua tujuan pembelajaran matematika tersebut oleh National Council of Teachers of Mathematics (NCTM) masing-masing dinamakan kemampuan komunikasi matematis (mathematical communication) dan mathematical disposition (NCTM, 2000).Kedua kemampuan tersebut termasuk 
ke dalam bagian dari kemampuan standar matematika sekolah. National Council of Teacher of Mathematics (NCTM) yang menyatakan satu di antara kemampuan komunikasi matematis adalah menggunakan bahasa matematis untuk menyatakan ide-ide matematika dengan tepat.

Selanjutnya, dalam kapasitas peningkatan kemampuan kognitif, project based learning menawarkan kesempatan untuk mengeksplorasi konsep-konsep matematika. Hal ini memberikan cara baru merepresentasikan konsep secara kompleks, dan membuat arti baru bagi siswa dan guru memanipulasi objek-objek yang abstrak dengan tangannya sendiri. Menurut Van de Walle (2002: 5) komunikasi matematis merupakan suatu cara untuk berhubungan dengan suatu ide matematis dan menyampaikannya kepada orang lain. Belajar menggunakan komunikasi dalam matematika dapat membantu perkembangan interaksi dan pengungkapan ide-ide di dalam kelas karena siswa belajar dalam suasana aktif (Van de Walle, 2002: 4). Pernyataan tersebut menyiratkan bahwa proses pembelajaran memerlukan komunikasi matematis untuk menyampaikan ide matematika. Karena itu, komunikasi matematis merupakan kecakapan yang harus dikuasai oleh siswa.

Namun kenyataannya secara umum bahwa mutu proses pembelajaran matematika belum tekankankan pada aspek komunikasi matematis. Hal ini terungkap pada rendahnya aspek komunikasi matematis terutama di Indonesia, Laporan dari Trends in International Mathematics and Science (TIMSS) dan Programe for International Student Assesment (PISA) pada tahun 2000 dan 2007 (Kemdikbud dalam Kunandar, 2013: 18) menunjukkan bahwa sajian soal yang menuntut kemampuan komunikasi matematis siswa, menterjemahkan diagram atau grafik ke dalam bahasa atau ide matematika, hanya $1,15 \%$ siswa yang menjawab benar $1,35 \%$ menjawab separuh benar $75,93 \%$ mencoba menjawab tetapi salah dan yang tidak menjawab $21,57 \%$.

Hasil studi pendahuluan di SMA Negeri 1 Kabupaten Landak menunjukkan bahwa sebagian besar siswa masih lemah dalam mengkomunikasikan konsep matematika.
Hal ini teridentifikasi oleh, misalkan pada saat siswa diminta membaca rumus luas permukaan kubus $\mathrm{L}=6 \mathrm{~s}^{2}$ siswa hanya membaca sesuai simbol yang ditampilkan tanpa ada makna yang siswa mengerti. Selanjutnya, ketika siswa diberikan permasalahan berupa soal-soal pemecahan masalah siswa enggan untuk mengerjakannya bahkan ia menyerah sebelum mencoba menyelesaikan soal tersebut. Rendahnya motivasi siswa untuk belajar, hal ini tampak pada kurangnya perhatian siswa terhadap hasil belajar yang diperoleh dan siswa terkesan pasrah, bahkan ketika mendapatkan nilai rendahpun siswa tersebut tidak melakukan perbaikan.

Rendahnya sikap positif siswa terhadap matematika, rasa percaya diri dan keingintahuan siswa berdampak pada hasil pembelajaran yang rendah.Hal tersebut senada dengan yang dikemukakan oleh Syaban (2009: 113) "Pada saat ini, daya dan disposisi matematis siswa belum tercapai sepenuhnya". Hal tersebut antara lain karena: (1) pembelajaran cenderung berpusat pada guru yang menekankan pada proses prosedural; (2) tugas latihan yang mekanistik, dan kurang memberi peluang kepada siswa untuk mengembangkan kemampuan berpikir matematis; dan (3) guru dalam mengajar berpedoman pada buku teks sementara sajian dari buku teks kurang memperhatikan kompetensi komunikasi dan disposisi matematis siswa.

Padahal Bishop (dalam Sugiatno dan Rif'at, 2009: 6) memperingatkan bahwa sebenarnya buku teks yang ditulis oleh para matematikawan ditujukan kepada para koleganya (para matematikawan lain). Peringatan ini menyiratkan bahwa bila pengajar secara langsung mengkomunikasikan isi buku teks tersebut kepada para siswa atau mahasiswa tanpa adanya alat bantu (strategi membaca), maka cukup beralasan sekiranya terjadi kesenjangan antara apa yang dikomunikasikan oleh buku teks itu dengan apa yang diterima oleh siswa atau mahasiswa (Sugiatno dan Rif'at, 2009: 6).

Berdasarkan penjelasan sebelumnya menunjukkan bahwa, betapa pentingnya kemampuan komunikasi dan disposisi matematisdalam proses pembelajaran 
matematika. Oleh karena itu, untuk mengembangkan dan meningkatkan kemampuan komunikasi dan disposisi matematis perlu dilakukan perubahan pembelajaran matematika dari pembelajaran berpusat pada guru ke pada siswa. Keaktifan dalam proses pembelajaran perlu ditunjang dengan disediakannya proses pembelajaran yang mendorong kemampuan matematis untuk menemukan dan membangun matematika dengan difasilitasi oleh guru. Satu di antara pendekatan yang disarankan adalah pendekatan pembelajaran yang menghasilkan karya berbasis proyek (project based learning).

Klein et. al (dalam Teresia Widyanti, 2014: 3-4) menjelaskan bahwa pembelajaran berbasis proyek (project based learning) merupakan strategi pembelajaran yang memberdayakan siswa untuk memperoleh pengetahuan dan pemahaman baru berdasar pengalamannya melalui berbagai presentasi. Adapun karakteristik pembelajaran berbasis proyek (project based learning) adalah siswa menyelidiki ide-ide penting dan bertanya, menemukan pemahaman dalam proses menyelidiki, sesuai dengan kebutuhan dan minatnya, menghasilkan produk dan berpikir kreatif, kritis dan terampil menyelidiki, menyimpulkan materi, serta menghubungkan dengan masalah dunia nyata.

Selanjutnya kelebihan pembelajaran berbasis proyek (project based learning) adalah:Meningkatkan motivasi siswa, kemampuan memecahkan masalah, meningkatkan keaktifan dan kolaborasi siswa;Meningkatkan keterampilan siswa dalam mencari informasi;Mendorong siswa untuk mengembangkan keterampilan komunikasi;Memberikan pengalaman kepada siswa dalam mengorganisasi proyek dan membuat alokasi waktu untuk menyelesaikan tugas; dan Menyediakan pengalaman belajar yang melibatkan siswa sesuai dunia nyata; dan membuat suasana belajar menjadi menyenangkan.

Hal ini sejalan dengan hasil penelitian Heide Spruck Wrigley dalam Sabar Nurohman (2013: 12) menunjukkan bahwa penerapan Project Based Learning membuat siswa mengalami proses pembelajaran yang bermakna, dengan memberikan kesempatan siswa untuk menggali sendiri informasi melalui membaca berbagai buku secara langsung, mempresentasikan kepada orang lain, mengkomunikasikan hasil aktivitasnya, bekerja dalam kelompok, mengajukan usul atau gagasannya untuk orang lain dan berbagai aktivitas lainnya. Hal itu menggambarkan bagaimana orang dewasa belajar secara lebih bermakna.Oleh karena itu dalam penelitian ini mengangkat topik: "Pembelajaran dengan Pendekatan Project Based Learning dan Pengaruhnya Terhadap Kemampuan Komunikasi dan Disposisi Matematis Siswa di Sekolah Menengah Atas".

\section{METODE}

Bentuk penelitian ini adalah kuantitatif. Sedangkan pendekatan yang digunakan dalam penelitian iniadalah One Group Pretest Posstest Study. Subjek populasi penelitian ini adalah seluruh siswa kelas XII SMA Negeri 1 Kabupaten Landak, dengan sampel siswa kelas XII.Subjek populasi dalam penelitian ini adalah siswa SMA Negeri 1 Kabupaten Landak kelas XII. Sedangkan sampel penelitian ini adalah kelas XII . Pengambilan sampel dilakukan menggunakan tehnik simple random sampling, diambil dari data penilaian kepraktisan menurut guru dan penilaian atau pendapat siswa berdasar tingkatan kemampuan yang berbeda (atas-tengahbawah).

\section{HASIL DAN PEMBAHASAN}

Pada penelitian ini terdapat dua kelompok data, yaitu: data pretes dan data postes yang diperoleh dari 39 siswa. Skor rerata aspek komunikasi matematis pretes $(11,10)$ dan postes $(12,77)$. Sedangkan disposisi matematis diperoleh rerata postes $(53,92)$.

Kenaikan hasil belajar siswa setelah mengikuti pembelajaran menggunakan pendekatan Project Based Learning dapat dilihat pada diagram berikut. 


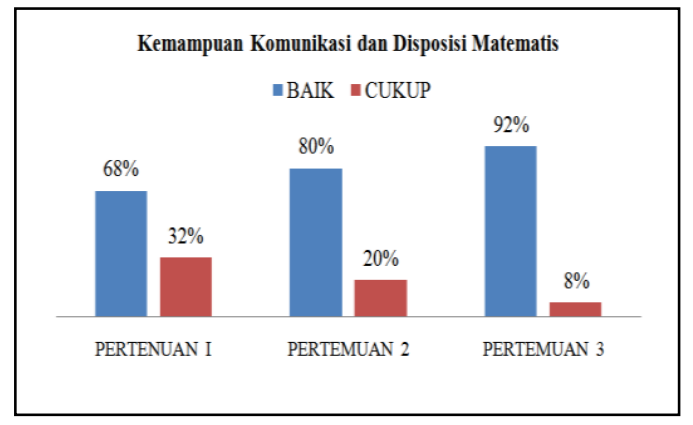

Diagram 1. Deskriptif Kemampuan Komunikasi dan Disposisi Matematis Siswa

Berdasarkan Diagram 1 perolehan hasil tes kemampuan komunikasi dan disposisi matematis siswa secara keseluruhan disetiap pertemuan mengalami peningkatan. Pertemuan 1 ketuntasan belajar siswa mencapai 68\% (kategori sedang), selanjutnya pertemuan 2 ketuntasan belajar siswa mencapai $80 \%$ (kategori tingggi). Sedangkan pertemuan 3 ketuntasan belajar siswa mencapai 92\% (kategori sangat tinggi).

Melalui bagian ini dikemukakan beberapa pembahasan yang berkaitan dengan hipotesis penelitian. Sesuai dengan hasil uji hipotesis 1 dan 2 (terdapat peningkatan terhadap kemampuan komunikasi matematis siswa sesudah diberikan pembelajaran dengan menggunakan pendekatan PBL dan terdapat peningkatan terhadap kemampuan disposisi matematis siswa sesudah diberikan pembelajaran menggunakan pendekatan PBL) bahwa secara signifikan menerima hipotesis $\mathrm{H}_{\mathrm{a}}$. Artinya, pembelajaran matematika menggunakan pendekatan PBL dalam materi bangun ruang mempengaruhi kemampuan disposisi dan komunikasi matematis siswa. Oleh karena itu, kemampuan komunikasi dan disposisi matematis siswa mengalami peningkatan yang signifikan berdasarkan nilai pretes ke postes yaitu sebesar (1.67). Peningkatan rerata skor pretes dan postes disebabkan oleh proses pembelajaran menggunakan pendekatan PBL. Hal ini teruji secara empirik bahwa pembelajaran dengan pendekatan PBL dapat diserap mereka, hal ini didasarkan pada rerata hasil postes yaitu 12.77. Hasil ini ternyata terkonfirmasi oleh penelitian terdahulu yang dilakukan oleh Rais, M (2010) dan Harding (2007) yang menyatakan bahwa terjadi peningkatan yang signifikan antara pretes dan postes setelah belajar menggunakan pendekatan PBL dan dapat mengembangkan pikiran reflektif dan keterampilan memecahkan masalah.

Selanjutnya jika dilihat berdasarkan hasil observasi aktivitas selama proses pembelajaran, peningkatan hasil belajar dari rerata prites ke postes disebabkan oleh: (1) proses pembelajaran dengan pendekatan PBL yang digunakan berbeda dari proses pembelajaran sebelumnya (konvensional), yaitu adanya kolaborasi antar siswa yang secara langsung memberikan pengalaman kepada siswa dalam mengorganisasi proyek dan melibatkan siswa sesuai dunia nyata serta dapat membuat suasana belajar menjadi menyenangkan; (2) kegiatan proses pembelajaran secara kooperatif atau PBL (diskusi) melibatkan siswa secara aktif dalam melakukan aktivitas matematis, seperti meningkatkan keterampilan siswa dalam mencari dan mengelola informasi, kemampuan memecahkan masalah, dan mendorong siswa untuk mengembangkan keterampilan komunikasi; dan (3) siswa terlibat langsung dalam melakukan diskusi dengan rekannya maupun dengan guru mengenai permasalahan terkait materi bangun ruang khususnya materi kubus dan balok, sehingga siswa dapat mengkontruksi dan mengevaluasi argumen-argumen rekannya. Serta dapat melakukan generalisasi saat penarikan kesimpulan.

Hal tersebut sejalan dengan teori Vygotsky (dalam Sugiatno, 2009: 19) yang menekankan pada kontruksi suatu pengetahuan pada aspek eksternal melalui proses sosiocultural. Menurut Vygostky (dalam Sugiatno, 2009: 19), proses kontruksi pengetahuan itu terjadi karena: (1) fungsi dan pentingnya bahasa dalam komunikasi social; (2) zona of proximal development (ZPD). Dosen atau guru sebagai mediator memiliki peran mendorong dan menjembatani siswa dalam upayanya membangun pengetahuan, pengertian dan kompetensi.Peran ini dinamakan scaffolding (penopang), sehingga siswa semakin lama semakin bertanggung jawab terhadap pembelajarannya sendiri. Misalnya, dalam pengajaran timbal balik, guru memimpin kelompok-kelompok kecil siswa untuk mengajukan pertanyaan terkait bangun ruang yang telah mereka pelajari dan 
secara bertahap mengalihkan tanggungjawab untuk memimpin diskusi tersebut kepada siswa lain.

Pengalaman-pengalaman yang dibawa seseorang (siswa) ke sebuah situasi pembelajaran dapat sangat mempengaruhi hasil belajar. Oleh karena itu perkembangan kognitif siswa bergantung pada seberapa jauh siswa aktif memanipulasi dan berinteraksi aktif dengan lingkungannya. Hal ini mengindikasikan bahwa lingkungan di mana siswa belajar sangat menentukan proses perkembangan kognitifnya. Ketika siswa bersama teman-teman sebayanya bekerja sama mengerjakan tugas-tugas, interaksiinteraksi sosial yang sama-sama mereka jalani dapat berperan sebagai fungsi pengajaran. Melalui komunikasi dan tindakan, orang-orang yang berada dalam lingkungan anak mengajarkan alat-alat kepada anak (misalnya, bahasa simbol, tanda) yang mereka butuhkan untuk memperoleh kompetensi (Schunk, 2012: 581).Interaksi sosial dengan guru, orang tua dan teman sebaya yang lebih berpengalaman memberikan kontribusi yang signifikan bagi perkembangan intelektual dan kemampuan disposisi maupun komunikasi matematis siswa.

Selanjutnya, jika mencermati Diagram 1 perolehan hasil tes kemampuan komunikasi dan disposisi matematis siswa secara keseluruhan disetiap pertemuan mengalami peningkatan. Hal ini menunjukkan bahwa materi prasyarat sebelum pembelajaran cukup dikuasai siswa sehingga dapat disimpulkan bahwa siswa siap menerima materi pelajaran baru dan materi bangun ruang terjangkau oleh pikiran siswa. Hal ini didasarkan pada: pertemuan 1 siswa belum dapat menjelaskan ide atau situasi dari suatu gambar atau grafik yang diberikan dengan kata-kata sendiri dalam bentuk tulisan, maupun menyatakan suatu situasi dengan gambar atau grafik, dan jawaban yang diberikan menunjukkan ketidakpahaman konsep.

Pertemuan 2 siswa dapat melukiskan diagram, gambar, atau tabel secara lengkap dan benar, namun penjelasan konsep kurang tepat, ide atau situasi dari situasi gambar yang diberikan dalam bentuk kalimat, dimana kalimat tersebut secara matematik dapat dipahami (bermakna) dan benar. Selanjutnya pada pertemuan 3 siswa sudah mampu menyatakan suatu situasi ke dalam bentuk model matematika (simbol), maupun gambar dengan benar.Penjelasan konsep, ide atau situasi gambar yang diberikan dalam bentuk kalimat, dimana kalimat tersebut secara matematik dapat dipahami (bermakna), benar dan jelas, serta tersusun secara logis dan runtut.

Pengaruh pendekatan PBL terhadap perkembangan yang dialami siswa terlihat pada tahapan presentasi, dalam hal ini setiap kelompok dilatih berpikir kritis dalam menanggapi masalah, memberi solusi, dan saling memberi penilaian. Hal paling penting dari proses ini adalah cara siswa mengkonstruksi belajarnya secara aktif dan tidak lagi diintervensi oleh guru secara penuh, tetapi cukup memfasilitasi keinginankeinginan siswa ketika mengajukan suatu pertanyaan. Di sinilah belajar secara bermakna ditemukan melalui kegiatan membuat perencanaan, penemuan, kolaboratif, penyelesaian masalah, tukar ide, saling memberi penilaian hingga melahirkan pengetahuan baru sebagai hasil belajar.

PBL memberikan ruang gerak bagi pembelajar dalam berkreasi dan melakukan kerja proyek dalam upaya menemukan informasi-informasi baru dari berbagai sumber informasi. Halil (2008) menegaskan bahwa PBL membantu penyelidikan yang mengarah pada pebelajar dalam menyelesaikan masalah-masalah nyata yang lebih luas, memberikan kesenangan dalam belajar, dan akan menjadi pembelajaran yang efektif dan strategis. Pembelajaran ini sangat baik diterapkan untuk meningkatkan hasil belajar pada aspek disain dan keterampilan motorik.

Secara umum, pembelajaran melalui pendekatan PBL terhadap soal-soal komunikasi matematis, siswa berpendapat positif. Pada aspek yang pertama, siswa menyukai pelajaran matematika, karena dipengaruhi cara guru mengajar yaitu diskusi berbasis pendekatan PBL. Sedangkan pada aspek yang kedua, banyak faktor yang menyebabkan siswa termotivasi dan aktif untuk belajar matematika, antara lain mengerjakan LKS secara berdiskusi untuk membantu teman sekelompok dalam rangka 
memperoleh nilai kelompok tertinggi. Hal ini juga didukung dari hasil wawancara dengan siswa, bahwa belajar kelompok dengan cara berdiskusi akan membantu siswa dalam memahami materi pelajaran dan dengan mengerjakan LKS, siswa lebih bersemangat lagi dalam belajar matematika.

Selanjutnya, pada aspek yang ketiga, siswa juga menunjukkan sikap positif. Hal ini dapat dilihat dari jawaban siswa yang merasakan manfaat dari mengerjakan soalsoal matematis untuk menyelesaikan permasalahan dalam kehidupan sehari-hari. Dengan demikian dapat disimpulkan bahwa siswa mempunyai sikap yang positif terhadap pembelajaran matematika yang disampaikan menggunakan pendekatan PBL.

Dengan demikian, siswa yang memiliki disposisi tinggi terlihat lebih gigih, tekun, dan berminat untuk mengeksplorasi hal-hal baru. Hal ini menjadikan siswa tersebut memiliki pengetahuan lebih dibandingkan siswa yang tidak menunjukkan perilaku demikian. Selanjutnya pengetahuan lebih itu akan berimplikasi pada terbentuknya kompetensi komunikasi matematis, termasuk pemecahan masalah matematis. Dengan demikian jelas bahwa disposisi matematis memang merupakan satu diantara faktor yang menunjang kemampuan pemecahan masalah matematis. Hal ini sejalan dengan pendapat Anku (dalam Mahmudi, 2010: 5) yang mengungkapkan bahwa satu faktor yang mempengaruhi proses dan hasil belajar matematika siswa adalah disposisi mereka terhadap matematika.

Hal ini dikarenakan masing-masing siswa bisa bertukar pikiran atau pendapat dan lebih leluasa bertanya bila ada teman sekelompok yang mengalami kesulitan, hal ini dapat membantu teman sekelompoknya untuk meningkatkan nilai kelompok sendiri. Demikian juga siswa mau bertanya kepada teman sekelompok, jika ada yang belum dimengerti, karena mereka berusaha untuk memahami materi dalam mempersiapkan turnamen akademik (persentasi maupun menyelesaikan soal-soal yang diberikan). Tetapi, kalau masih bingung juga, mereka sekelompok minta penjelasan langsung dari guru.

Pada umumnya siswa senang belajar dengan LKS, karena lebih mudah mengerjakannya dan ada teori singkat pada pada LKS tersebut. Ada juga di antara mereka yang menjawab dengan adanya LKS, mereka tidak perlu menulis soal lagi sehingga langsung dapat membahas dan mengerjakannya. Adapun waktu yang disediakan untuk berdiskusi dan mempelajari materi tiap pertemuan, pada umumnya siswa merasa cukup. Siswa bisa mengeksplorasi kemampuannya dalam pembelajaran bangun ruang menggunakan pendekatan PBL, bahan ajar dan LKS dapat membantu siswa dalam memahami materi matematika yang sedang dibahas, karena siswa langsung membaca teori singkat, dan mengerjakan persoalan tanpa menulis soal terlebih dahulu, dan semua sudah disiapkan di LKS sehingga dapat mengefektifkan waktu yang digunakan. Mereka merasa mendapat pengalaman lebih dengan belajar matematika khususnya materi bangun ruang.

Selanjutnya belajar menggunakan pendekatan PBL dapat merangsang siswa untuk belajar lebih aktif, karena siswa dapat menunjukkan kebenaran rumus-rumus yang selama ini dijelaskan secara manual. Pendekatan PBL menyajikan permasalahanpermasalahan yang menggali pemikiran dan logika siswa terhadap topik materi yang sedang dipelajari serta menuntut siswa untuk berpikir lebih luas. Untuk memperoleh penyelesaian masalah yang lebih luas adalah dengan cara bertukar pendapat atau diskusi. Diskusi yang aktif membantu siswa menjadi lebih mandiri dalam mencari informasi tentang materi yang akan dipelajari, informasi dapat dicari di berbagai media pembelajaran baik dari buku maupun media yang lain.

Selain itu siswa juga memiliki kemahiran dalam berinteraksi dengan sesama siswa sehingga dapat menumbuhkan bakat intelektual siswa dalam mensintesis dan menganalisis. Hal tersebut sesuai dengan pendapat Sudjana (1996: 93) yang menyatakan kelebihan pendekatan PBL yaitu siswa memperoleh pengalaman praktis, kegiatan belajar lebih menarik sehingga tidak membosankan, bahan pengajaran lebih dihayati dan dipahami oleh para siswa, siswa dapat belajar dari berbagai sumber, interaksi sosial antar peserta lebih berkembang, siswa belajar melakukan analisis dan sintesis secara 
simultan serta membiasakan siswa berpikir logis dan sistematis dalam pemecahan masalah.

Penelitian ini menunjukkan partisipasi dan keaktifan berdiskusi siswa meningkat dengan diterapkannya pendekatan PBL pada proses belajar mengajar, terdapat variasi metode, antara lain diskusi dan tanya jawab. Sehingga siswa secara langsung dapat mempraktekkan metode tersebut dan akhirnya siswa akan lebih aktif dalam proses belajar mengajar. Siswa yang lebih pandai dapat memberikan pendapat serta dapat menjawab pertanyaan dari siswa yang kurang paham, sedangkan bagi siswa yang kurang paham dapat bertanya pada siswa lainnya. Hal ini tidak berarti bahwa siswa yang kurang pandai tidak dapat mengambil bagian dari proses belajar mengajar menggunakan pendekatan PBL.

Menurut Attle dan Baker (2007: 79), siswa yang memiliki prestasi akademik yang tidak terlalu tinggi memiliki kesempatan untuk ikut serta dalam kelompok dan dapat memberikan kontribusi kepada kelompoknya dengan maksimal pada saat proses pembelajaran menggunakan pendekatan PBL, contohnya dengan mengatur tugas, sebagai penengah bila ada anggota kelompok yang berselisih paham, ikut andil dalam mengambil keputusan dan memfasilitasi komunikasi antar anggota kelompok. Pendekatan PBL merupakan pendekatan pembelajaran yang cukup efektif dalam pembelajaran. Hal ini dapat dilihat pada meningkatnya partisipasi dan keaktifan berdiskusi siswa.

Lebih lanjut Attle dan Baker (2007: 79) menyatakan bahwa pembelajaran dengan diskusi terbuka dan berorientasi pada pemecahan masalah akan memperkuat hubungan antar siswa sebagai anggota kelompok serta membantu mengembangkan, menggabungkan dan memilih alternatif pemecahan masalah yang dihadapi bersama. Penelitian ini berhasil menerapkan pendekatan PBL untuk meningkatkan partisipasi dan keaktifan berdiskusi siswa dibandingkan dengan pembelajaran konvensional. Hal ini sesuai dengan pendapat Turgut (2009: 55) yang menyatakan bahwa pendekatan PBL lebih efektif dari pada pembelajaran tradisional dalam melatih kemampuan dan ketrampilan siswa serta dapat menguatkan memori pengetahuan dan keterampilan siswa selama proses pembelajaran berlangsung. Hal ini karena pengetahuan dibentuk sendiri oleh siswa dari kegiatan diskusi kelompok untuk memecahkan masalah yang dihadapi selama proses belajar mengajar berlangsung.

Berdasarkan kajian teoritis dengan menganalisis proses Scientific Method dan sintak pendekatan PBL, maka dapat disimpulkan bahwa: pendekatan PBLmemiliki tahap-tahap pembelajaran yang selaras dengan proses SM. Oleh karena itu, pendekatan PBL secara teoritis dapat digunakan sebagai sarana internalisasi nilai dan semangat SM.

\section{SIMPULAN}

Simpulan yang berkaitan dengan masalah penelitian sebagai berikut: (1) kemampuan disposisi matematis dalam materi bangun ruang sesudah diberikan pembelajaran menggunakan pendekatan Project Based Learning mengalami peningkatan yang signifikan. Adapun indikator yang mempengaruhi yaitu: memiliki rasa ingin tahu dalam bermatematika, rasa percaya diri dalam menyelesaikan masalah matematika, dan gigih serta ulet dalam mengerjakan tugastugas; (2) kemampuan komunikasi matematis dalam materi bangun ruang sesudah diberikan pembelajaran menggunakan pendekatan Project Based Learning mengalami peningkatan yang signifikan. Adapun indikator yang mempengaruhi yaitu: menjelaskan ide atau situasi dari suatu gambar atau grafik yang diberikan dengan kata-kata sendiri dalam bentuk tulisan, dan menyatakan suatu situasi ke dalam bentuk model matematika (simbol); dan (3) pendekatan Project Based Learning memberikan kontribusi positif terhadap kemampuan komunikasi matematis siswa dalam materi bangun ruang, terutama dalam menjelaskan ide atau situasi dari suatu gambar atau grafik yang diberikan dengan kata-kata sendiri dalam bentuk tulisan, menyatakan suatu situasi dengan gambar atau grafik, dan menyatakan suatu situasi ke dalam bentuk model matematika (simbol). 


\section{DAFTAR PUSTAKA}

Attle, Simon dan Bob Baker. (2007). Cooperative Learning a Competitive Environment: Classroom Applications. International Journal of Teaching and Learning in Higher Education. 19 (1), 77-83. Diakses tanggal 10 Agustus 2009.

Badan Standar Nasional Pendidikan. (2006). Standar Isi dan Kompetensi Dasar SMP/MTs. Jakarta: BSNP.

Bistari.BsY. (2010). Pengembangan Kemandirian Belajar Berbasis Nilai Untuk Meningkatkan Komunikasi Matematik. Jurnal Pendidikan Matematika dan IPA Vol. 1.No. 1. Januari 2010: 11-23.

Depdikbud. (2013b). Peraturan Menteri Pendidikan dan Kebudayaan Nomor 81, Tahun 2013, Tentang Implementasi Kurukulum. Jakarta: Depdiknas.

Emzir. (2013). Metode Penelitian Pendidikan Kuantitatif \& Kualitatif. Jakarta: PT Raja Grafindo Persada.

Halil, T. (2008). Prospective of Science Teachers Conceptualizations about Project-Based Learning. International Journal of Instruction, 1(1): 61-79.

Harding, T.S. (2007). Work-in-ProgressSelf Directed Learning and Motivation in a Project-based Learning Environment.ASEE/IEEE Frontiers in Education Conference, (online) (http://www.fie.engrng.pitt.edu, diakses 22 November 2008).

Kunandar. (2013). Penilaian Autetik (Penilaian Hasil Belajar Peserta Didik Berdasarkan Kurikulum 2013) Suatu Pendekatan Praktik Disertai Dengan Contoh. Jakarta. Rajawali Press.

Mahmudi, A. (2010). Tinjauan Asosiasi antara Kemampuan Pemecahan Masalah Matematis dan Disposisi Matematis.Makalah disajikan pada Seminar Nasional Pendidikan Matematika.Yogyakarta.

National Countil of Teachers of Mathematics. (2000). Principle and Standards for Schools Mathematics. Resto. VA.
Rais, M. \& Mustari. (2010). Pengembangan Model Project Based Learning (MPBL): Suatu Upaya Meningkatkan Prestasi Akademik Mahasiswa Jurusan Teknik Mesin. Laporan Penelitian Hibah Bersaing. Lembaga Penilitian UNM. Makassar.

Sabar Nurrohman. (2013). Pendekatan Project Based Learning Sebagai Upaya Internalisasi Scientific Method Bagi Mahasiswa Calon Guru Fisika. Jurnal.

Schunk, D. H. (2012). Learning theories an educational perspective. Boston: Person.

Sudjana, Nana. (1996). CBSA Cara Belajar Siswa Aktif dalam Proses Belajar Mengajar. Bandung: Sinar Baru.

Sugiatno, Rif'at, M. (2009). MengembangkanKemampuan

Komunikasi Matematis Mahasiswa Calon Guru Melalui Perkuliahan Matematika Dengan Menggunakan Model Pembelajaran Transactional Reading Strategy.Pontianak: Universitas Tanjungpura. Jurnal.

Syaban, M. (2009)."Menumbuh kembangkan Daya dan Disposisi Matematis Siswa Sekolah Menengah Atas Melalui Pembelajaran Investigasi".Jurnal Educationist Vol. III No. 2 Juli 2009.

Teresia Widyanti. (2014). Penerapan Model Project Based Learning(Model Pembelajaran Berbasis Proyek) dalam Materi Pola Bilangan Kelas VII. Jurnal.

Turgut, Halil. (2008). Perspective Science Teachers' Conceptualizations about Project Based Learning. International Journal of Instruction. 1 (1), 76-79. Diakses tanggal 10 Agustus 2009.

Van De Walle, John A. (2002). Matematika Sekolah Dasar dan Menengah Pengembangan Pengajaran Jilid 2. Jakarta: Erlangga. Teachers. Center for Mathematical Inquiry Current Research, (Online), (http://math.ucsb.edu/department/cmi/

$\frac{\text { Covaria }}{\text { diakses }} \quad 27 \frac{\text { tionFunctionPaper.pdf }}{\text { juni }}$ 2013).

